\title{
Large spatial scale variation of demersal fish assemblage structure on the continental shelf of the NW Mediterranean Sea
}

\author{
Jean-Claude Gaertner ${ }^{1, *}$, Jacques A. Bertrand ${ }^{2}$, Luis Gil de Sola ${ }^{3}$, \\ Jean-Pierre Durbec ${ }^{1}$, Eduardo Ferrandis ${ }^{4}$, Arnauld Souplet ${ }^{5}$ \\ ${ }^{1}$ Centre d'Océanologie de Marseille, LMGEM, UMR CNRS 6117, Rue de la batterie des Lions, 13007 Marseille, France \\ ${ }^{2}$ IFREMER, Laboratoire Ecologie Halieutique, Rue de l'Ile d'Yeu, BP 21105, 44311 Nantes Cedex 03, France \\ ${ }^{3}$ Centro Oceanográphico de Málaga (I.E.O.), Puerto pesquero s/n, 29640 Fuengirola (Málaga), Spain \\ ${ }^{4}$ University of Alicante, 03080 Alicante, Spain \\ ${ }^{5}$ IFREMER, Laboratoire Ressources Halieutiques, Bv Jean Monnet, BP 171, 34203 Sète, France
}

\begin{abstract}
The spatial structure of demersal fish assemblages on the continental shelf of the NW Mediterranean Sea was examined on a large scale between the Straits of Gibraltar and the Gulf of Lions. In contrast to its predominant role in the spatial distribution of species composition, described worldwide, it seems depth has only a limited effect on the distribution patterns of the total abundance and diversity of demersal fishes. In addition, evidence is provided for the division of the whole study area into 3 geographical fish assemblages. The influence of Atlantic inputs and the semi-permanent Almería-Oran hydrographic front play a key role in defining the Alboran Sea as a specific fish fauna area. Moreover, the clear differentiation between 2 distinct assemblages in the Gulf of Lions and the Catalan Sea could be partly linked to the North Balearic front. These results contribute to the current debate on the definition of spatial units for the purpose of demersal fisheries management. They also stress the complexity of developing an ecosystem approach which deals simultaneously with species composition and biodiversity aspects of ecosystems management.
\end{abstract}

KEY WORDS: Demersal fishes · Assemblage structure - Species diversity · Management units · Mediterranean Sea

Resale or republication not permitted without written consent of the publisher

\section{INTRODUCTION}

A central issue in fisheries ecology is determining the various factors underlying spatial variation in community structure, in order to include ecosystem considerations in fishery management (Menge \& Olson 1990, Mahon et al. 1998, Garrison \& Link 2000). Most observational studies have therefore examined community organization through regional scale analyses of species composition or species diversity patterns. Studies dedicated to species composition evidence the strong dominance of bathymetry in determining demersal assemblage patterns (Mahon \& Smith 1989, Gordon \& Bergstadt 1992, Fujita et al. 1995, Garcia et al. 1998, Moranta et al. 1998, Hyndes et al. 1999, Mueter \&
Norcross 1999, Bertrand et al. 2000, Magnussen 2002). Other factors, such as water temperature, salinity and bottom type, commonly appear to play secondary roles in species composition structure (Mahon \& Smith 1989, Bianchi 1992, Rakosinski et al. 1992, Perry et al. 1994, Auster et al. 1995, Gaertner et al. 1999, Demestre et al. 2000). By contrast, spatial patterns of demersal fish species diversity and the associated causal factors are less clear and vary greatly from one study to the other (e.g. Weinberg 1994, Barber et al. 1997, Mueter \& Norcross 1999, Magnussen 2002).

For several years, community ecologists have been pointing out the need to complete local and regional studies on a larger scale (Ricklefs 1987, Menge \& Olson 1990, Mahon et al. 1998). This trend is based on 
the premise that ecological patterns exhibited on large spatial scales are linked to important structuring ecological processes (Gustafson 1998, Gaston 2000) and can be relevant for use as a basis for fisheries management (Garibaldi \& Caddy 1998, Mahon et al. 1998, Sherman \& Duda 1999). However, the paucity of largescale surveys using a standardized sampling design has greatly limited the number of studies examining demersal fish communities on large spatial scales (see Bianchi 1991, Mahon et al. 1998, Williams et al. 2001).

This worldwide situation is particularly apparent in the Mediterranean Sea, where only the work of JukicPeladic et al. (2000) in the Adriatic Sea and Cartes et al. (2002) along the coast of the Iberian Peninsula were carried out on a large spatial scale. However, due to the high level of multispecies fisheries activity, there has been increasing demand from Mediterranean authorities for clearly defined biogeographical areas as references for management purposes (Caddy 1998, Anonymous 2001a,b). The overall aim is the progression towards a more integrated approach through the concept of exploited ecosystem management (Anonymous 2001c).

With this in mind, the present study aimed to analyse the spatial organization patterns of the demersal fish assemblages on a large scale in the NW Mediterranean Sea. We thus analysed data collected by the Mediterranean International Trawl Survey programme (MEDITS) with a single sampling design over the continental shelf of 6 areas located between the Straits of
Gibraltar and the eastern part of the Gulf of Lions. Assuming assemblage structure to be a multidimensional concept, we simultaneously quantified species composition, species diversity and total abundance of assemblages. The questions addressed in this study are: (1) does each sampled area have a different fish assemblage structure pattern, (2) what are the key environmental gradients along which the assemblages are structured, and (3) does the spatial organization of demersal assemblages allow the breaking down of the NW Mediterranean Sea into geographical assemblage units for management purposes?

\section{MATERIALS AND METHODS}

Study sites and sampling design. The data from 3 annual bottom trawl surveys performed in 1996 (112 tows), 1997 (118 tows) and 1998 (119 tows) between the Straits of Gibraltar and the eastern part of the Gulf of Lions within the framework of the MEDITS project (Bertrand et al. 2000, 2002a) were analysed (Fig. 1). The sampling procedures of these surveys were standardised according to a common protocol, including use of the same gear and the same sampling strategy for the whole zone studied. Two research vessels were used, the RV 'Cornide de Saavedra' along the Iberian Peninsula and the RV 'L'Europe' in the Gulf of Lions, in order to achieve the sampling of the whole area during only a short time period (May to June in the same year).

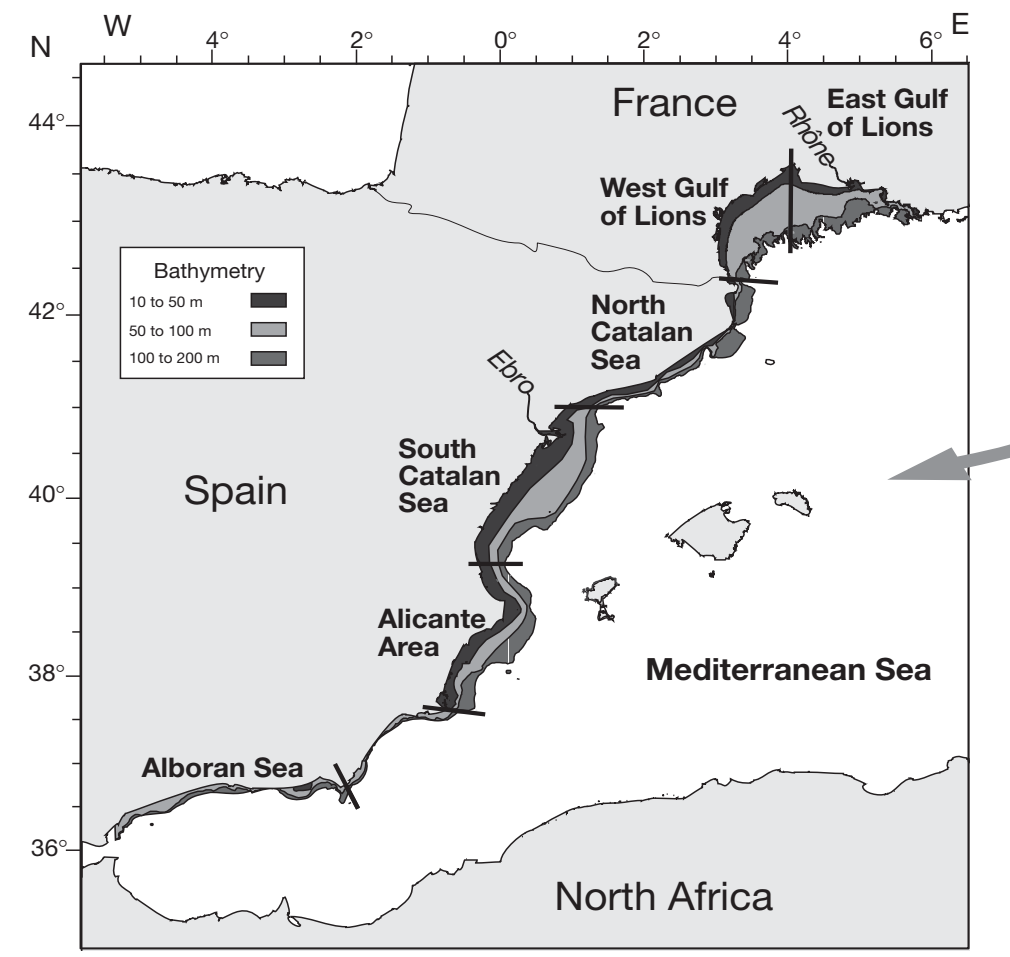

Fig. 1. Map of the study zone with boundaries of the 6 areas sampled 
The standard device was a bottom trawl (GOC 73, Fiorentini et al. 1999) with $20 \mathrm{~mm}$ cod-end mesh size (stretched mesh). Hauls were performed during daylight hours and their standard duration was $30 \mathrm{~min}$. All the tows were performed at a speed of 3 knots. An underwater Scanmar system was systematically used to control the trawl geometry (horizontal and vertical openings, contact with the bottom). The vertical opening of the gear was about $2 \mathrm{~m}$, and its wing spread about $18 \mathrm{~m}$ (Bertrand et al. 2002b). A preliminary analysis of the Scanmar data allowed us to take only the tows properly sampled into account. The abundance indices were converted into density (number of individuals by species and per $\mathrm{km}^{2}$ ) for each haul studied.

A stratified random-sampling design was used, based on depth and geographical areas. First, the continental shelf was divided into 3 depth strata: 10 to $50 \mathrm{~m}$ (66 tows), 50 to $100 \mathrm{~m}$ (199 tows) and 100 to $200 \mathrm{~m}$ (84 tows). Secondly, the whole study zone was divided into several geographical operative areas for the allocation of samples. This stratification was performed by each operational scientific team, based on their knowledge of the environmental characteristics of the area surveyed (Bertrand et al. 2000, 2002a).

Allocation of tows in each depth strata and geographical sector was roughly proportional to the surface of the corresponding stratum and geographical sector. The 6 operating areas considered in our analysis were defined as follows:

The Alboran Sea is delimited by the Straits of Gibraltar to the west and Cape Gata to the east. A total of 31 tows were analysed during the study period. This region is characterized by a very narrow continental shelf, as well as the direct influence of surface Atlantic waters, entering the Mediterranean through the Straits of Gibraltar (Millot 1999).

The Alicante Area (48 tows) stretches from Cape Palos in the south to Valencia (Sagunto) in the north. Here, the continental shelf is wider than in the Alboran Sea, and surface inflowing (modified) Atlantic and outflowing Mediterranean waters meet around the Ibiza sill (Abelló et al. 2002). The gap between the Alboran and Alicante areas (Fig. 1) is due to the topography of this zone, i.e. it was difficult to sample properly in such a narrow shelf.

The Catalan Sea is bordered by the Iberian peninsula in the north and west and the Balearic islands in the south. This area has been split into 2 operational geographical units at $41^{\circ} \mathrm{N}$. The northern part of this area (36 tows) features a narrow continental shelf hollowed out by submarine canyons. The southern part (63 tows) is characterized by the presence of the Ebro river and by the widest continental shelf (up to $70 \mathrm{~km}$ ) of the Iberian Mediterranean coast.

The Gulf of Lions features a very wide continental shelf mainly due to the presence of the Rhône river delta in its eastern part. With a catchment basin of about $98000 \mathrm{~km}^{2}$, the Rhône river is the biggest source of inland flow into the Mediterranean Sea. This area has been split into 2 operational geographical units at $4^{\circ} \mathrm{E}$ : the western part (98 tows) and the eastern part ( 73 tows), the latter being directly under the influence of the Rhône river plume.

Dividing up the whole study zone in this way provided a basis for determining whether pre-existing geographical sectors-defined on the basis of their topographic and ecological features (size of the shelf, presence of a big river, direct influence of the Atlantic inflow, etc.) showed any heterogeneity (or similarity) for each of the community descriptors considered. In comparison to an overall approach using all the data with no a priori division into sectors, our strategy allows statistical testing of differences in each of the community descriptors between geographical sectors (see 'Statistical analyses').

Statistical analyses. We investigated the spatial patterns of demersal fish assemblage structure through the analysis of total abundance, species richness, evenness and species composition. Total number of individuals per $\mathrm{km}^{2}$ was used as an index of total fish abundance at each site. Following Wilsey \& Potvin (2000), we split species diversity into 2 major components: species richness (the number of species at a given station), and species evenness (how well abundance is distributed among species within an assemblage). We used Pielou's Evenness Index $\left(J=-\sum p_{i} \log _{2} p_{i} / \log _{2}(S)\right.$, where $p_{i}$ is the proportion of all individuals belonging to species $i$ and $S$ is the number of species).

Firstly, several generalized linear models (GLMs, McCullagh \& Nelder 1989) were used to investigate the effects of year, bathymetric stratum and sampled region on the variation of each of the 3 univariate descriptors of assemblages (total abundance, species richness and evenness). The link functions were identity or logarithm and the error term was assumed to be normally distributed. Taking into account the large number of observations considered in our study ( $\mathrm{n}=349)$ - which increases the power of the statistical tests - we always chose the $1 \%$ threshold as the limit of significance (rather than 5\%, as is sometimes the case for smaller data sets). We did not include linear interactions of second and third orders between factors, because they were non-significant and did not alter the results of the models (as displayed by the difference in the deviance between the models with and without interaction term). Secondly, the results of these GLMs were used to assess regional means for each of the community descriptors after adjustment for both the depth and year effects (least-square means). Lastly, the least-square means (LS means) were compared using Tukey's multiple comparison method (Hsu \& Nelson 1998). 
In addition, multivariate analyses were carried out to test for significant heterogeneity in the overall species composition due to annual or regional effects. The influence of depth (and correlated environmental factors) on demersal fish species composition was not analysed, because it has been extensively described both worldwide and for the Mediterranean Sea (Gaertner et al. 1999, Ungaro et al. 1999, Rélini et al. 1999, Demestre et al. 2000, Biagi et al. 2002). Moreover, because very few reliable environmental data on depth-correlated factors are available across our study zone, it would have been difficult to provide new information on their respective influence on the bathymetric pattern of fish species composition.

We used between-group correspondence analyses (Dolédec \& Chessel 1990), where a group is a categorical factor (for instance the 6 sampled areas) that the analysis uses as instrumental variables (to test the between-area variability of species composition). In the first stage, the between-group analysis seeks axes that will best discriminate the centres of gravity of each group. The second stage involves the projection of the different stations as supplementary rows, and thereby highlights the variability of each row (here station) around the centre of gravity of its corresponding group. It allows the assessment of the homogeneity of the species composition (1) within each group for the factor tested and (2) between stations belonging to the different groups. In the present study, this allowed $a$ posteriori assessment of the influence of depth on the inter-regional pattern of species composition of demersal fish assemblages. In addition, a permutation test extended from Romesburg's (1985) to all kinds of variables (see Manly 1991) was carried out to test the significance of the between-group variability. The general principle of the between-group analysis was in some aspects similar to the Fisher Linear Discriminant Analysis (Mardia et al. 1992). The main difference was that Discriminant analysis was based on the Mahalanobis distance whereas correspondence betweengroup analysis allowed us to use the chi-square metric. In contrast to analyses using Euclidian or Mahalanobis distances, the use of chi-square on faunistic tables enabled us to obtain an exact typology of the stations based on the similarity of their species composition. For previous examples of the use of between-group analysis in the field of community ecology, see Dolédec \& Chessel (1994), Gaertner et al. (1998) or Blanc et al. (2001).

Species occurring in less than $1 \%$ of the tows (i.e. no more than 3 times among the 349 tows) were ruled out, the only exception being species occurring 3 times in the same operative area. This was in order to reduce the problem of accidental species without losing too much information on the faunistic specificity of the regions sampled. The resulting fauna list included 70 fish demersal species. The analysis of species composition revealed only 60 species (Appendix 1) sufficiently abundant to be included in the multivariate analysis (i.e. present in more than $5 \%$ of tows). Values of abundance per $\mathrm{km}^{2}$ were transformed $(\ln [x+1])$ before analysis to minimise the dominant effect of exceptional catches. The GLMs and Tukey multiple-comparison procedure were performed using SAS (SAS/STAT, 1992) while the ADE-4 software (Thioulouse et al. 1996) was used to perform all the calculations and graphic displays for the between-group analyses. (This software is available free of charge at: http://pbil.univlyon.fr/ADE-4.html.)

\section{RESULTS}

\section{Total abundance and species diversity indices}

Variations of each of the 3 community descriptors (total abundance, species richness and evenness) were analysed according to 3 factors (year of sampling, depth stratum and geographical sector) using GLMs (Table 1). In all 3 cases, the proportion of variability explained by the model was highly significant ( $p<0.0001)$, showing that each community descriptor is influenced by the factors considered. Table 1 provides a rough comparison of the separate influence of each factor on each community descriptor. We observed that the geographical sector seemed to be the most important factor in the variation for species richness $\left(F_{5,343}=29.64, \mathrm{p}<0.0001\right)$ while depth stratum and year played a weaker role $\left(F_{2,346}=14.83\right.$, $\mathrm{p}<0.0001$ and $F_{2,346}=6.67, \mathrm{p}=0.0014$, respectively). In contrast, our results suggest that depth stratum is the most important factor of variation for evenness $\left(F_{2,346}=20.52, \mathrm{p}<0.0001\right)$ while geographical sector plays a weaker role $\left(F_{5,343}=11.60, \mathrm{p}<0.0001\right)$ and the year of sampling is not significant $\left(F_{2,346}=0.63\right.$, $\mathrm{p}=0.53)$. Log-abundance is also mainly influenced by depth stratum $\left(F_{2,346}=31.61, \mathrm{p}<0.0001\right)$, while geographical sector $\left(F_{5,343}=18.19, \mathrm{p}<0.0001\right)$ and especially year $\left(F_{2,346}=6.41, \mathrm{p}=0.0025\right)$ are of more limited influence. Thus, in each model, depth stratum and geographical sector have a stronger influence than the year of sampling, which appeared to play, at best, a very limited role in the variation of the community descriptors. Moreover, we also have to keep in mind that each of the models explains only a limited part of the total variation of the community descriptors (see $\mathrm{R}^{2}$ which varies from 0.23 for evenness to 0.33 for abundance and 0.37 for species richness). The inherent high noise in this kind of trawl survey data partly explains the relatively low level we observed for $\mathrm{R}^{2}$. 
Variation of total abundance and species diversity indices according to depth

The use of non-parametric Loess regression allows the variation of each of the univariate assemblage descriptors according to depth to be specified (Fig. 2). A slight increase was found in the logarithm of the total abundance with depth (Fig. 2a), while the opposite trend was observed for evenness (Fig. 2c). Species richness exhibited a non-linear relationship with depth. This diversity index mainly reached maximum values between 80 and $120 \mathrm{~m}$ depth (Fig. 2b). Nevertheless, these figures also show that, for each of the assemblage descriptors considered, several tows at a given depth can give very different values. This observation highlights that the observed trends were subject to strong variability and emphasizes the weakness of the relation between bathymetry and each of the studied descriptors (total abundance, species richness and evenness).

Variation of total abundance and species diversity indices between the geographical areas

Here, our goal was to assess the between-areas heterogeneity for each of the univariate community descriptors considered. A comparison of the variation of each of these descriptors from one geographical sector to another after adjustment for depth and year effects is provided (Fig. 3, Table 2). For the logarithm of total abundance, maximum values were observed in the western part of the Gulf of Lions and in the Alboran Sea. Total abundance in the western Gulf of Lions appeared to be significantly higher than that observed in the Catalan Sea, the eastern part of the Gulf of Lions and the Alicante area (Table 2, Tukey multiple-comparison test, $\mathrm{p}<0.05)$. The Alboran Sea shows only significantly higher values than those recorded in both the North Catalan Sea and Alicante area. The western part of the Gulf of Lions exhibited significantly higher values for species richness than those recorded in the 5 other areas. For the North Catalan Sea, the opposite situation was apparent. There, species richness appeared to be significantly lower than that observed in all the other areas, except for the South Catalan Sea.
More generally, although they are 2 geographically adjoining areas, the whole of the Gulf of Lions (eastern and western parts) and the whole Catalan Sea (northern and southern parts) showed opposite values for species richness. For evenness, a smooth transition was found from the highest zones (southern part of the Catalan Sea, eastern part of the Gulf of Lions and the Alicante area) to the lowest ones (western Gulf of Lions, northern Catalan Sea, Alboran Sea). Among the 3 univariate assemblage descriptors studied, species richness exhibited the most strongly contrasted regional pattern (Table 2).

\section{Species composition of the assemblages}

Variation of species composition over the period studied

A between-group analysis focused on the annual effect was carried out to test the occurrence of a significant annual variation of the species composition of the assemblages during the period studied. The permutation test (1000 permutations) associated with this analysis did not reveal the occurrence of significant temporal variation $(p>0.05)$ in the overall species composition. On the contrary, it showed that the interannual component of inertia only took into account $2.05 \%$ of the total inertia. We therefore concluded that the inter-annual variability of the species composition of the demersal fish assemblages was negligible during the period studied.

Table 1. General results of the GLMs. NS: non-significant effect

\begin{tabular}{|c|c|c|c|c|c|c|}
\hline $\begin{array}{l}\text { Dependent } \\
\text { variable }\end{array}$ & Source & df & SS & MS & $F$ & $\mathrm{p}>F$ \\
\hline \multirow{6}{*}{$\begin{array}{l}\text { Abundance } \\
(\log ) \\
\left(\mathrm{R}^{2}=0.33\right)\end{array}$} & Model & 9 & 30.75 & 3.41 & 18.56 & $<0.0001$ \\
\hline & Error & 339 & 62.41 & 0.18 & & \\
\hline & Corrected total & 348 & 93.16 & & & \\
\hline & Year & 2 & 2.36 & 1.18 & 6.41 & 0.0025 \\
\hline & Depth & 2 & 11.64 & 5.82 & 31.61 & $<0.0001$ \\
\hline & Geographical area & 5 & 16.75 & 3.35 & 18.19 & $<0.0001$ \\
\hline \multirow{6}{*}{$\begin{array}{l}\text { Species } \\
\text { richness } \\
\left(\mathrm{R}^{2}=0.37\right)\end{array}$} & Model & 9 & 4465.84 & 496.21 & 21.25 & $<0.0001$ \\
\hline & Error & 339 & 7918.21 & 23.35 & & \\
\hline & Corrected total & 384 & 12163.14 & & & \\
\hline & Year & 2 & 311.73 & 155.9 & 6.67 & 0.0014 \\
\hline & Depth & 2 & 693.01 & 346.5 & 14.83 & $<0.0001$ \\
\hline & Geographical area & 5 & 3461.1 & 692.22 & 29.64 & $<0.0001$ \\
\hline \multirow[t]{2}{*}{ Evenness } & Model & 9 & 2.30 & 0.25 & 11.13 & $<0.0001$ \\
\hline & Error & 339 & 7.79 & 0.02 & & \\
\hline \multirow[t]{4}{*}{$\left(\mathrm{R}^{2}=0.23\right)$} & Corrected total & 348 & 10.09 & & & \\
\hline & Year & 2 & 0.03 & 0.01 & 0.63 & $0.53(\mathrm{NS})$ \\
\hline & Depth & 2 & 0.94 & 0.47 & 20.52 & $<0.0001$ \\
\hline & Geographical area & 5 & 1.32 & 0.26 & 11.60 & $<0.0001$ \\
\hline
\end{tabular}


Variation of species composition between the geographical areas

We carried out a between-group analysis focused on the geographical area effect in order to test the existence of regional heterogeneity in the species composition within the zone studied. This revealed that be-
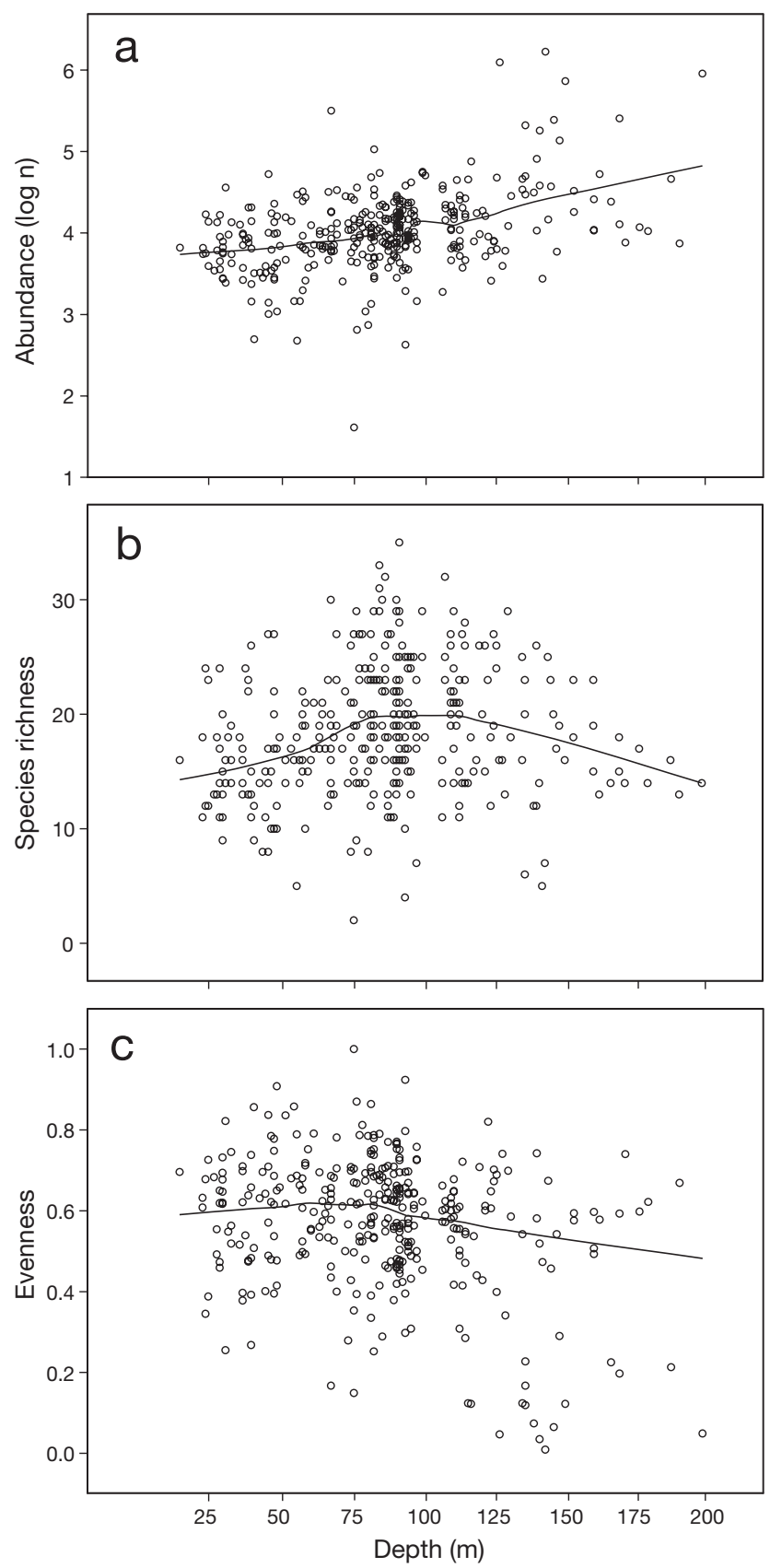

Fig. 2. Variation of (a) total abundance (in logarithm), (b) species richness and (c) evenness against depth. Continuous lines are estimations of the regression curves by the local nonparametric regression method (Loess) tween-area inertia accounted for $21.25 \%$ of the total variability. The associated permutation test was highly significant $(p<0.001)$, which showed that the area subdivision considered in the present study showed significant heterogeneity in the species composition of the fish assemblages. The first plane of the betweenarea analysis accounted for $88.3 \%$ of the total between-
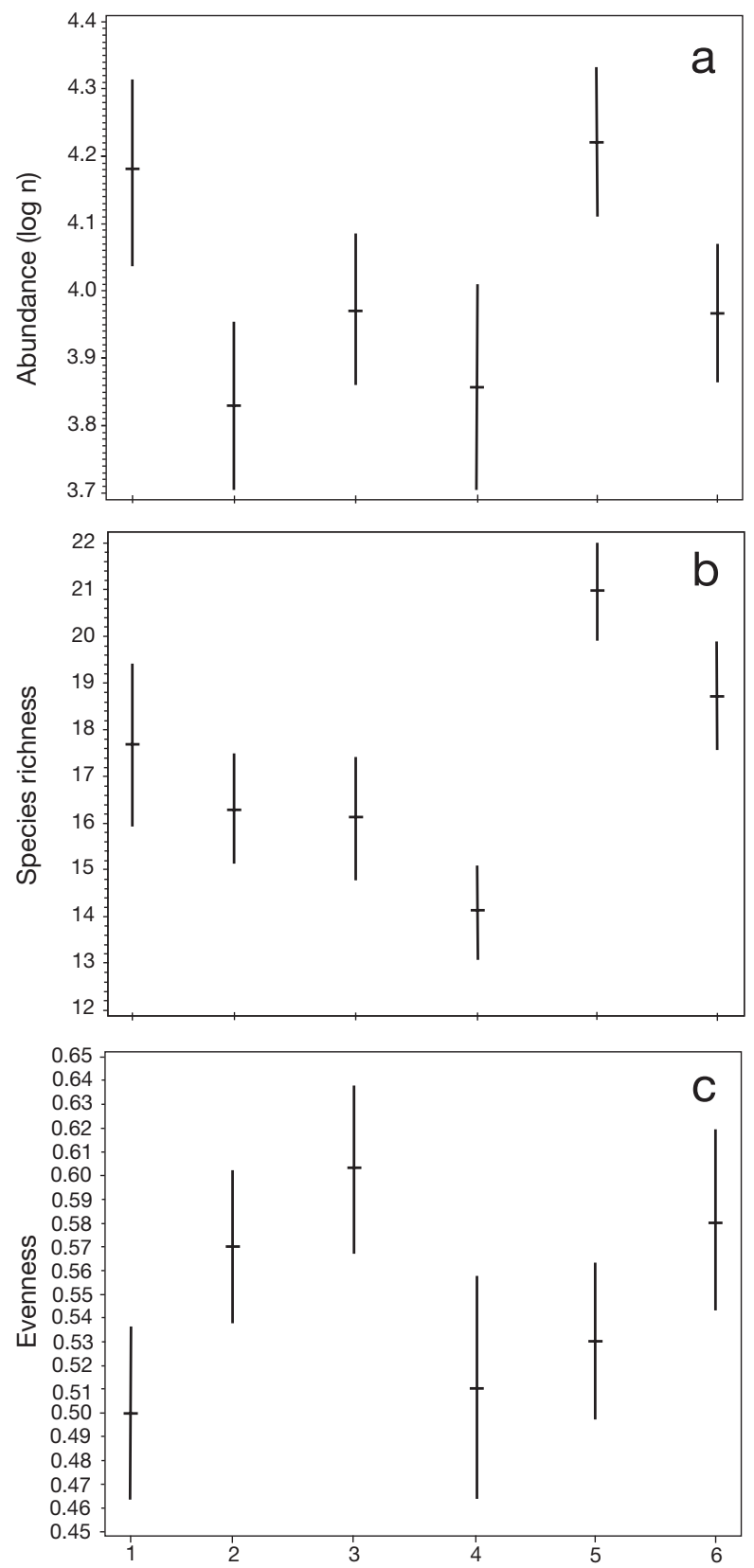

Fig. 3. Means and $95 \%$ confidence intervals for (a) total abundance (in logarithm), (b) species richness and (c) evenness at the 6 geographical sectors. Means are computed after adjustment for both depth and year effects (least-squares means). Area codes: (1) Alboran Sea; (2) Alicante area; (3) South Catalan Sea; (4) North Catalan; (5) West Gulf of Lions; (6) East Gulf of Lions 
Table 2. Comparison of mean values for total abundance, species richness and evenness for the 6 geographical sectors. LS means: least-squares regional means after adjustment for both depth and year effects. Geographical sectors with the same letter are not significantly different (Tukey's multiple-comparison method, $\mathrm{p}<0.05$ )

\begin{tabular}{|c|c|c|c|c|c|c|c|c|c|c|c|c|c|c|}
\hline \multirow{2}{*}{$\begin{array}{l}\begin{array}{l}\text { Geographical } \\
\text { sector }\end{array} \\
\text { West Lions }\end{array}$} & \multicolumn{4}{|c|}{$\begin{array}{l}\text { Total abundance (log) } \\
\text { LS means }\end{array}$} & \multirow{2}{*}{$\begin{array}{l}\begin{array}{l}\text { Geographical } \\
\text { sector }\end{array} \\
\text { West Lions }\end{array}$} & \multicolumn{4}{|c|}{$\begin{array}{l}\text { Species richness } \\
\text { LS means }\end{array}$} & \multirow{2}{*}{$\begin{array}{l}\begin{array}{l}\text { Geographical } \\
\text { sector }\end{array} \\
\text { South Catalan }\end{array}$} & \multicolumn{4}{|c|}{$\begin{array}{l}\text { Evenness } \\
\text { LS means }\end{array}$} \\
\hline & 4.22 & A & & & & 20.94 & A & & & & 0.60 & A & & \\
\hline Alboran & 4.18 & A & B & & East Lions & 18.72 & B & & & East Lions & 0.58 & A & B & \\
\hline South Catalan & 3.97 & & B & $\mathrm{C}$ & Alboran & 17.68 & B & $\mathrm{C}$ & & Alicante & 0.57 & A & B & \\
\hline East Lions & 3.96 & & B & $\mathrm{C}$ & Alicante & 16.28 & & $\mathrm{C}$ & & West Lions & 0.53 & & B & $\mathrm{C}$ \\
\hline North Catalan & 3.86 & & & $\mathrm{C}$ & South Catalan & 16.13 & & & $\mathrm{D}$ & North Catalan & 0.51 & & B & $\mathrm{C}$ \\
\hline Alicante & 3.84 & & & $\mathrm{C}$ & North Catalan & 14.16 & & & $\mathrm{D}$ & Alboran & 0.50 & & & $\mathrm{C}$ \\
\hline
\end{tabular}

area inertia and thus provided a good summary of this between-area heterogeneity (Fig. 4). The projection of the different trawl stations (symbolized by small square boxes) as supplementary rows enabled us to assess the degree of variability of the species composition in each of the 6 operative MEDITS areas (Fig. 4a). In Fig. 4, the proximity between stations was directly linked to the similarity of their species composition.

All the stations sampled in the Alboran Sea were projected into the same factorial area and they were well discriminated from the 5 other MEDITS sampled operational areas. Consequently, on the scale used here, the Alboran Sea can be considered as a specific faunistic region. The Alicante area and the whole Catalan Sea can be considered as a second faunistic region. Due to strong overlapping between the stations of these 3 areas, it was difficult to distinguish them from one other on the basis of species composition. Moreover, the tows from the Alicante area and the Catalan Sea appeared to be well discriminated from the 3 other operative MEDITS areas (indicating that their species composition was different from that observed in these areas).

Similar, but even more striking, results were found for the 2 parts of the Gulf of Lions. The strong overlap between the projections of the stations of these 2 areas indicates that they exhibited a very similar species composition pattern. Thus, the whole Gulf of Lions is considered as a third specific faunistic region.

Fig. 4a clearly shows that the new partition of the 6 geographical sectors into 3 faunistic regions is independent of the bathymetry. Despite strong withinregion differences in depth - each geographical sector and then each faunistic region is represented by several stations belonging to each of the 3 bathymetric

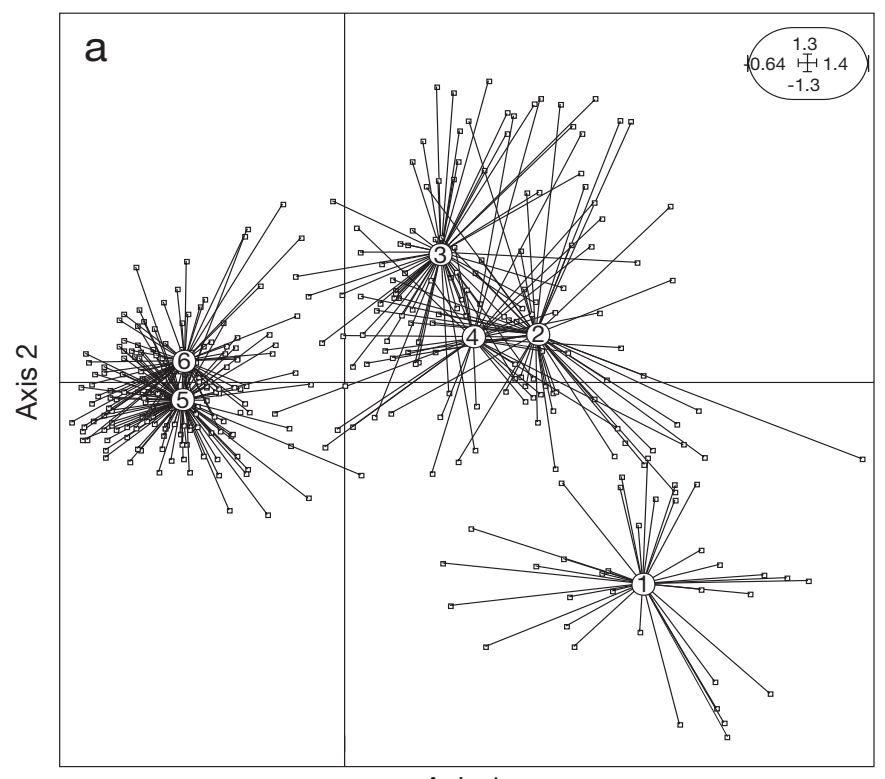

Axis 1

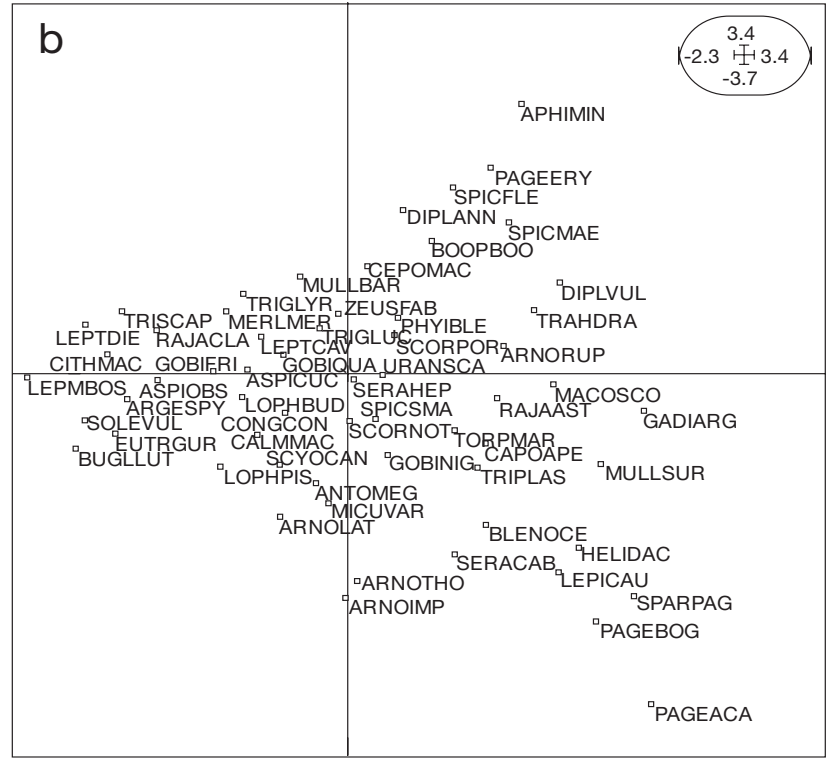

Axis 1

Fig. 4. First factorial plan of the between-group correspondence analysis (Axis 1: horizontal, Axis 2: vertical). (a) Projection of the 6 operational areas. Area codes as in Fig. 3. The projection of each station (small square boxes) is related to the corresponding area. (b) Projection of the species. For species codes see 'Appendix 1'. Scale box in the upper right corner of each plot indicates the limits for the first and second axes 
strata: 10 to $50 \mathrm{~m}, 50$ to $100 \mathrm{~m}$ and 100 to $200 \mathrm{~m}$ - each of the stations in each of the 3 identified regions (Alboran, Alicante-Catalan Sea and Gulf of Lions) was clearly distinguished from the stations of the other 2 regions. This result shows that the partition of the whole study zone into 3 specific faunistic regions occurred at all depths considered and thus does not appear to be influenced by bathymetry.

The projection of the species onto the first factorial plane of the between-area analysis (Fig. 4b) allowed identification of the main taxa responsible for this regional zonation. Species such as Pagellus acarne, $P$. bogaraveo, Lepidopus caudatus, Helicolenus dactylopterus, or Blennius ocellaris exhibited an abundance peak in the Alboran Sea. Other species such as Aphia minuta, P. erythrinus, Diplodus annularis, Spicara maena, or Boops boops were strongly associated with the Alicante-Catalan Sea region, while species such as Lepidorhombus boscii, Citharus linguatula, Lepidotrigla dieuzeidei, Chelidonichthys (Eutrigla) gurnardus, Buglossidium luteum, Argentina sphyraena and Solea solea mainly characterized the Gulf of Lions.

\section{DISCUSSION}

\section{Depth zonation of assemblage structure}

On the large spatial scale used, we observed that species richness tended to reach maximum values around 80 to $110 \mathrm{~m}$ depth. At the more restricted scale of the Gulf of Lions, Gaertner et al. (1998) evidenced the presence of 2 stable shelf demersal assemblages organized along a depth gradient with a boundary at around 80 to $100 \mathrm{~m}$ depth. Thus, the highest values for species richness observed in this depth range can be better seen as a superimposition zone between species belonging to a coastal assemblage and to a deeper one, rather than as a zone showing habitat characteristics particularly favourable for the development of fish species.

More generally, we have shown that the relationships between bathymetry and each of the assemblage descriptors were weak and marked by strong residual variability. A non-exhaustive analysis of the literature devoted to demersal fish assemblages revealed a wide variety of relationships between species richness and bathymetry along the continental shelves of the world ocean. Depending on the area studied, some authors have observed a positive relationship (Weinberg 1994, McClatchie et al. 1997, Thomas \& Connolly 2001), a negative relationship (Barber et al. 1997, Fariña et al. 1997), or even no relationship at all (Mueter \& Norcross 1999, Kallianiotis et al. 2000, Blanchard 2001). The analysis of the link between bathymetry and total abundance also seemed to be context-dependent (see e.g. Weinberg 1994 or Fujita et al. 1995 for positive correlation and Fariña et al. 1997 or Kallianiotis et al. 2000 for negative correlation). Results concerning evenness were less numerous, but they also evidenced some variability even in adjacent regions (see Magnussen 2002 for an illustration of this statement). This confusing situation and the weakness of the links we observed on a large scale suggest that the relationships between bathymetry and species diversity or total abundance were strongly influenced by other processes. Thus, in contrast to its universally described predominant role in the spatial distribution of species composition, depth may only have a limited effect on the distribution patterns of the total abundance and diversity of demersal fishes.

\section{Regional zonation of assemblage structure}

The species composition of the demersal fish assemblages appeared to be organized into 3 regions along a geographical southwest-northeast axis. The fact that each of the 6 sampled areas did not evidence a distinctive species composition pattern compared to the 5 others partly explains the relatively low level of between-area variability we observed $(21.25 \%)$. This was also limited because the spatial pattern of species composition of demersal fish assemblages was strongly structured by factors acting independently of this regional zonation. This is notably the case for the bathymetry, and for numerous factors such as bottom type or the physical and chemical characteristics of the water (see 'Introduction' for references). Thus, although it was not predominant, our results show that this regional pattern was highly significant $(p<0.001)$ and the clear discrimination of each of the 3 identified regions (see Fig. 4a) emphasized its importance in terms of demersal fish organization.

The regional faunistic pattern observed could be associated with the environmental heterogeneity of the zone studied. In the southern part of the area, the Alboran Sea is strongly influenced by the Atlantic currents entering the Mediterranean through the Straits of Gibraltar (Millot 1999). The thickness of this vein, called Modified Atlantic Water, is generally greater than $200 \mathrm{~m}$ in the Alboran Sea (Millot 1999). This results in a local area of high productivity (Abelló et al. 2002) and induces strong organic rain (Minas et al. 1984). Harmelin \& d'Hondt (1993) postulated that 'an undegraded portion of this sedimentation reaches the benthos when depth is not too great and enhances the benthos food resources'. These authors further suggested that this trophic supply could favour the survival of Atlantic macrofauna species which have crossed through the Gibraltar Straits. This view is consistent 
with results from several studies which have demonstrated the marked influence of Atlantic inputs on several benthic invertebrate groups such as the bryozoans (Harmelin \& D'Hondt 1993), the sponges (Maldonado \& Uriz 1995), the hydrozoans (Medel \& López-González 1996), and the crustaceans (Abelló et al. 2002) in the Alboran Sea. These observations are also consistent with the earlier work of Pérès \& Picard (1964), who observed a high rate of species of Atlantic affinity in the macrofauna of the continental shelf of the Alboran Sea.

It has been widely demonstrated that species composition of benthic invertebrates influenced the presence and the abundance of many demersal fish species (see Cartes et al. 2002 for an illustration of this statement for the Iberian Peninsula). We can therefore assume that the clear differentiation of a demersal assemblage in the Alboran Sea can be mainly linked to the influence of Atlantic waters, notably through the strong occurrence of macrofauna species of Atlantic affinity in this area. In addition, as previously suggested by several authors (e.g. Caddy 1998, Abelló et al. 2002), the stable presence of the Almería-Oran hydrographical front in the north-eastern part of the Alboran Sea could also contribute to delimiting this area to the east.

The analysis presented here clearly distinguishes 2 other demersal fish assemblages associated with the Alicante-Catalan area and with the Gulf of Lions, respectively. We also show that the Gulf of Lions and the Alicante-Catalan areas give contrasting results from a species richness viewpoint, with maximum and minimum levels respectively. These clear differences in demersal fish assemblage structure patterns strongly contrast with their similarity in terms of their main environmental features. The presence of the Rhône river in the eastern part of the Gulf of Lions and the Ebro river in the southern part of the Catalan Sea, which were among the most important sources of freshwater and nutrient inflow into the Mediterranean Sea (Margalef 1985, Levourch et al. 1992), strongly mark the environmental features of these 2 regions. The influence of rivers on demersal species in the Mediterranean Sea has been evidenced in several works. The commercially exploited crustaceans Squilla mantis appear to be preferentially abundant in areas under the influence of the Rhône (Do Chi 1975) and Ebro (Abelló \& Sarda 1989, Abelló \& Martin 1993). Concerning demersal fishes, the influence of rivers has been observed for Mullus barbatus (Lombarte et al. 2000) in the Ebroinfluenced-area, and Citharus linguatula (Gaertner et al. 1999) and Solea solea (Salen-Picard et al. 2002) for the region under the influence of the Rhône river plume. At the species assemblage organizational level, the works of Demestre et al. (2000), restricted to the Catalan Sea, did not discriminate a specific assemblage associated with the Ebro runoff. Similarly, the clear difference in species composition and species richness we observed between the 2 regions under the influence of the Ebro and Rhône rivers suggest that river discharges do not have a key influence on fish demersal patterns at assemblage organizational level.

This faunistic pattern differentiation between the Gulf of Lions and the Alicante-Catalan area can be partly explained by the influence of a mesoscale hydrographic structure. The geographical boundary between the assemblages of these 2 zones roughly corresponds to the location of the North Balearic front. This hydrographic structure, which vertically extends down to about $200 \mathrm{~m}$, is generally attached to the coast in the axis of the Pyrenees mountains (LeVourch et al. 1992). In the Mediterranean Sea, the potential effect of some semipermanent or permanent hydrographic structures on fish distribution patterns has been already suggested especially, but not exclusively, for pelagic species (Caddy 1998, Agostini \& Bakun 2002). In SE New Zealand, McClatchie et al. (1997) postulated that mesoscale oceanographic features might specifically influence the distribution and diversity of demersal assemblages. Our results for the demersal fishes of the NW Mediterranean Sea strongly support this hypothesis.

\section{Identification of spatially distinct units for management purposes}

The results of the present study provide evidence for extending the faunistic specificity of the Alboran Sea, previously only mentioned for benthic invertebrate groups, to the demersal fishes. In addition, the large spatial scale of our study area, including both the Iberian peninsula and the Gulf of Lions, has made it possible to identify a second faunistic barrier around Cape Creus (French-Spanish border). Thus, our results suggest a division of the whole study area into 3 geographical fish assemblages.

This regional division, based solely on faunistic criteria, should be examined in light of those recently proposed by the General Fisheries Commission for the Mediterranean (GFCM) under the aegis of the FAO. The Mediterranean and Black Sea (FAO Area 37) has been recently re-organized by the Scientific Advisory Committee (SAC) of the GFCM in order to define management units for both demersal and small pelagic species (Anonymous 2001a). The actual definition of these management units is mainly based on political and geographical considerations which required the SAC to take into account (1) the limits of the fishery activities, (2) the national borders (3) the pre-existing GFCM statistical divisions and (4) the location of parallels and meridians. Despite the discrepancy of the 2 approaches, the number and the boundaries of the 
new management units adopted by the GFCM within our study zone (Anonymous 2001b) were totally consistent with the 3 faunistic regions we evidence in the present study. From this viewpoint, our results, which confirm the relevance of the zonation proposed by the GFCM, contribute to the identification of natural management areas, recognized as one of the key issues in Mediterranean fisheries management (Caddy 1998, Garibaldi \& Caddy 1998).

However, we also show that the different key components of the assemblage organization (species composition, total abundance, species richness and evenness) do not always exhibit the same spatial distribution pattern. This finding underlines the complexity of globally managing fisheries. On the one hand, defining regions characterized by a particular and stable species composition pattern appears to be a major challenge for multispecies fisheries management purposes (Mahon \& Smith 1989, Abelló et al. 2002, Biagi et al. 2002). On the other hand, identifying which geographical regions should be protected, in order to maintain the widest biological diversity, is central to the design of effective conservation programmes (Mahon \& Smith 1998, Reid 1998, Browman \& Stergiou 2004). Our analysis thus emphasizes that the question of what region to protect clearly depends on what we want to protect. In this regard, our results open the way to discussion of the introduction of an ecosystem approach in fishery management strategy, which deals simultaneously with species composition and biodiversity aspects of ecosystems management.

Acknowledgements. This study was carried out in the framework of both the demersal assemblages working group of the International MEDITS programme and of the French national programme PNEC-ART4. We wish to thank all participants in the surveys conducted along the Spanish and French coasts within the MEDITS programme. We also thank M. Paul for correcting the English.

\section{LITERATURE CITED}

Abelló P, Martin P (1993) Fishery dynamics of the mantis shrimp Squilla mantis (Crustacea: Stomatopoda) population off the Ebro delta (northwestern Mediterranean). Fish Res 16:131-145

Abelló P, Sarda F (1989) Some observations on the biology and fishery of Squilla mantis in the Catalan area (NW Mediterranean Sea). In: Ferrero EA (ed) Biology of stomatopods. Muchia Editore, Modena, p 229-239

Abelló P, Carbonell A, Torres P (2002) Biogeography of epibenthic crustaceans on the shelf and upper slope off the Iberian peninsula Mediterranean coasts: implications for the establishment of natural management areas. Sci Mar 66:183-198

Agostini VN, Bakun A (2002) Ocean triads in the Mediterranean Sea: physical mechanisms potentially structuring reproductive habitat suitability (with example application to European anchovy, Engraulis encrasicolus). Fish
Oceanogr 11:129-142

Anonymous (2001a) Working group on management units. General Fisheries Commission for the Mediterranean Scientific Advisory Committee, FAO-GFCM, Alicante, Spain, 23-25 January 2001, p 1-27

Anonymous (2001b) Report of the twenty-sixth session of the General Fisheries Commission for the Mediterranean, FAO-GFCM, Ischia, Italy, http://www.fao.org/docrep/ meeting/004/y1908e.htm

Anonymous (2001c) Basic principles of ecosystem management. Ecosystem management. Abstract from the FAO Fisheries atlas, Section 3.2.8. FAO, Rome, http://www. refisheries2001.org/sidur/ecosystem/ecosystem.htm

Auster PJ, Malatesta RJ, La Rosa SC (1995) Patterns of microhabitat utilization by mobile megafauna on the southern New England (USA) continental shelf and slope. Mar Ecol Prog Ser 127:77-85

Barber WE, Smith RL, Vallarino M, Meyer RM (1997) Demersal fish assemblages of the northeastern Chukchi Sea, Alaska. Fish Bull 95:195-209

Bertrand JA, Gil de Sola L, Papaconstantinou C, Relini G, Souplet A (2000) An international bottom trawl survey in the Mediterranean: the MEDITS programme. In: Bertrand J, Relini G (eds) Demersal resources in the Mediterranean. IFREMER, Plouzané

Bertrand JA, Gil de Sola L, Papaconstantinou C, Relini G, Souplet A (2002a) The general specifications of the MEDITS surveys. Sci Mar 66:9-17

Bertrand JA, Leonori I, Dremiere PY, Cosimi G (2002b) Depth trajectory and performance of a trawl used for an international bottom trawl survey in the Mediterranean. Sci Mar 66:169-182

Biagi F, Sartor P, Ardizonne GD, Belcari P, Belluscio A, Serena F (2002) Analysis of demersal assemblages off the Tuscany and Latium coasts (north-western Mediterranean). Sci Mar 66:233-242

Bianchi G (1991) Demersal assemblages of the continental shelf and slope edge between the gulf of Tehuantepec (Mexico) and the Gulf of Papagayo (Costa Rica). Mar Ecol Prog Ser 73:121-140

Bianchi G (1992) Demersal assemblages of the continental shelf and upper slope of Angola. Mar Ecol Prog Ser 81: 101-120

Blanc L, Aliaume C, Zerbi A, Lasserre G (2001) Spatial and temporal co-structure analyses between ichthyofauna and environment: an example in the tropics. CR Acad Sci 324: 635-646

Blanchard F (2001) Une approche de la dynamique des peuplements de poissons démersaux exploités: analyse comparée de la diversité spécifique dans le golfe de Gascogne (océan Atlantique) et dans le golfe du Lion (mer Méditerranée). Aquat Living Resour 14:29-40

Browman HI, Stergiou KI (2004) Perspectives on ecosystembased approaches to the management of marine resources. Mar Ecol Prog Ser 274:269-303

Caddy JF (1998) Issues in Mediterranean fisheries management: geographical units and effort control. Studies and reviews. General Fisheries Council for the Mediterranean, Vol 70. FAO, Rome

Cartes JE, Abello P, Lloris D, Carbonell A, Tores P, Maynou F, Gil de Sola L (2002) Feeding guilds of western Mediterranean demersal fish and crustaceans: an analysis based on a spring survey. Sci Mar 66:209-220

Demestre M, Sanchez P, Abello P (2000) Demersal fish assemblages and habitat characteristics on the continental shelf and upper slope of the north-western Mediterranean. J Mar Biol Assoc UK 80:981-988 
Do Chi T (1975) Biométrie de la reproduction de Squilla mantis (crustacés stomatopodes) dans le golfe d'Aigues Mortes (Méditerranée nord occidentale). Pubbl Staz Zool Napoli 39(Suppl 1):114-139

Dolédec S, Chessel D (1990) Rythmes saisonniers et composantes stationnelles en milieu aquatique. II. Prise en compte et élimination d'effets dans un tableau faunistique. Acta Oecolog Oecol Gener 10:207-232

Dolédec S, Chessel D (1994) Co-inertia analysis: an alternative method for studying species-environment relationships. Freshw Biol 31:277-294.

Fariña AC, Freire J, Gonzales-Gurriaran E (1997) Demersal fish assemblages in the Galician Continental Shelf and Upper Slope (NW Spain): spatial structure and long term changes. Estuar Coast Shelf Sci 44:435-454

Fiorentini L, Dremière PY, Leonori I, Sala A, Palumbo V (1999) Efficiency of the bottom trawl used for the Mediterranean International Trawl Survey (MEDITS). Aquat Living Resour 12:187-205

Fujita T, Tadashi I, Ishito Y (1995) Depth-gradient structure on the demersal fish community on the continental shelf and slope off Sendai Bay, Japan. Mar Ecol Prog Ser 118:13-23

Gaertner JC, Chessel D, Bertrand J (1998) Stability of spatial structures of demersal assemblages: a new approach. Aquat Living Resour 11:75-85

Gaertner JC, Mazouni N, Sabatier R, Millet B (1999) Spatial structure and habitat associations of demersal assemblages in the Gulf of Lions: a multicompartment approach. Mar Biol 135:199-208

Garcia CB, Duarte LO, Schiller D (1998) Demersal fish assemblages of the Gulf of Salamanca, Colombia (southern Caribbean Sea). Mar Ecol Prog Ser 174:13-25

Garibaldi L, Caddy JF (1998) Biogeographic characterization of Mediterranean and Black Sea faunal provinces using GIS procedures. Ocean Coast Manag 39:211-227

Garrison LP, Link JS (2000) Dietary guild structure of the fish community in the Northeast United States continental shelf ecosystem. Mar Ecol Prog Ser 202:231-240

Gaston KJ (2000) Global patterns in biodiversity. Nature 405: 220-227

Gordon JM, Bergstad OA (1992) Species composition of demersal fish in the Rockall Trough, North Eastern Atlantic, as determined by different travels. J Mar Biol Assoc UK 72:213-230

Gustafson EJ (1998) Quantifying landscape spatial pattern: what is the state of the art? Ecosystems 1:143-156

Harmelin JG, D'Hondt JL (1993) Transfers of bryozoan species between the Atlantic Ocean and the Mediterranean Sea via the Straits of Gibraltar. Oceanol Acta 16:63-72

Hsu JC, Nelson B (1998) Multiple comparisons in the General Linear Model. J Comput Graph Stat 7:23-41

Hyndes GA, Platell ME, Potter IC, Lenanton RCJ (1999) Does the composition of the demersal fish assemblages in temperal coastal water change with depth and undergo consistent seasonal changes? Mar Biol 134:335-352

Jukic-Peladic S, Vrgoc N, Krstulovic-Sifner S, Piccinetti C, Piccinetti-Manfrin G, Marano G, Ungaro N (2000) Longterm changes in demersal resources of the Adriatic Sea: comparison between trawl surveys carried out in 1948 and 1998. Fish Res 1106:1-10

Kallianiotis A, Sophronidis K, Vidoris P, Tselepides A (2000) Demersal fish and megafaunal assemblages on the Cretan continental shelf and slope (NE Mediterranean): seasonal variation in species density, biomass and diversity. Prog Oceanogr 46:429-455

Koopmans LH (1981) An introduction to contemporary statistics. Duxbury Press, Belmont, CA
Levourch J, Millot C, Castagne N, Le Borgne P, Olry JP (1992) Atlas des fronts thermiques en mer Méditerranée d'après l'imagerie satellitaire. Mem Inst Oceanogr (Monaco) 16: $1-145$

Lombarte A, Recasens L, Gonzalez M, Gil de Sola L (2000) Spatial segregation of two species of mullidae (Mullus surmuletus and Mullus barbatus) in relation to habitat. Mar Ecol Prog Ser 206:239-249

Magnussen E (2002) Demersal fish assemblages of Faroe Bank: species composition, distribution, biomass spectrum and diversity. Mar Ecol Prog Ser 238:211-225

Mahon R, Smith RW (1989) Demersal fish assemblages on the Scotian shelf, northwest Atlantic: spatial distribution and persistence. Can J Aquat Fish Sci 46:134-152

Mahon R, Brown SK, Zwanenburg KCT, Atkinson DB and 6 others (1998) Assemblages and biogeography of demersal fishes of the east coast of North America. Can J Fish Aquat Sci 55:1704-1738

Maldonado M, Uriz MJ (1995) Biotic affinities in a transitional zone between the Atlantic and the Mediterranean: a biogeographical approach based on sponges. J Biogeogr 22: 89-110

Manly BFJ (1991) Randomization and Monte Carlo methods in biology. Chapman \& Hall, London

Mardia KV, Kent JT, Bibby JM (1992) Multivariate analysis. Academic Press, New York

Margalef R (1985) Introduction to the Mediterranean. In: Margalef R (ed) Key environments: Western Mediterranean. Pergamon Press, Oxford, p 1-16

McClatchie S, Millar RB, Webster F, Lester PJ, Hurst R, Bagley N (1997) Demersal fish community diversity off New Zealand: is it related to depth, latitude and regional surface phytoplankton? Deep-Sea Res 44:647-667

McCullagh P, Nelder JA (1989) Generalized Linear Models, 2nd edn. Chapman \& Hall, London

Medel MD, Lopéz-González PJ (1996) Updated catalogue of hydrozoans of the Iberian Peninsula and Balearic Islands, with remarks on zoogeography and affinities. Sci Mar 60: 183-209

Menge BA, Olson AM (1990) Role of scale and environmental factors in the regulation of community structure. Trends Ecol Evol 5:52-57

Millot C (1999) Circulation in the western Mediterranean Sea. J Mar Syst 20:423-442

Minas HJ, Coste B, Minas M (1984) Océanographie du détroit de Gibraltar et des parages annexes. Courrier CNRS 57: $10-17$

Moranta J, Stefanescu C, Massuti E, Morales-Nin B, Lloris D (1998) Fish community structure and depth-related trends on the continental slope of the Balearic Islands (Algerian Basin, western Mediterranean). Mar Ecol Prog Ser 171: 247-259

Mueter F, Norcross B (1999) Linking community structure of small demersal fishes around Kodiak Island, Alaska, to environmental variables. Mar Ecol Prog Ser 190:37-51

Pérès JM, Picard J (1964) Nouveau manuel de bionomie benthique de la mer Méditerranée. Rec Trav Stn Mar Endoume 31:5-137

Perry RI, Smith SJ (1994) Identifying habitat associations of marine fishes using survey data: an application to the northwest Atlantic. Can J Fish Aquat Sci 51:589-602

Rakocinski CF, Baltz DM, Fleeger JW (1992) Correspondence between environmental gradients and the community structure of marsh-edge fishes in a Louisiana estuary. Mar Ecol Prog Ser 80:135-148

Reid WV (1998) Biodiversity hotspot. Trends Ecol Evol 13: $275-280$ 
Relini G, Bertrand J, Zamboni A (1999) Synthesis of the knowledge on bottom fishery resources in central Mediterranean (Italy and Corsica). Biol Mar Medit 6(Suppl 1)

Ricklefs RE (1987) Community diversity: relative roles of local and regional processes. Science 235:167-171

Romesburg HC (1985) Exploring, confirming and randomization tests. Comp Geogr 11:19-37

Salen-Picard C, Darnaude A, Arlhac D, Harmelin-Vivien M (2002) Fluctuations of macrobenthic populations: a link between climate-driven river run-off sole fishery yields in the Gulf of Lions. Oecologia 133:380-388

SAS/STAT (1992) SAS users. SAS Institute, Cary, NC

Sherman K, Duda AM (1999) An ecosystem approach to global assessment and management of coastal waters. Mar Ecol Prog Ser 190:271-287

Thioulouse J, Chessel D, Dolédec S, Olivier JM (1996) ADE-4: a multivariate analysis and graphical display software. Stat Comput 7:75-83
Thomas BE, Connolly RM (2001) Fish use of subtropical saltmarshes in Queensland, Australia: relationships with vegetation, water depth and distance onto the marsh. Mar Ecol Prog Ser 209:275-288

Ungaro N, Marano CA, Marsan R, Martino M, Marzano MC, Strippoli G, Vlora A (1999) Analysis of demersal species assemblages from trawl surveys in the South Adriatic Sea. Aquat Living Resour 12:177-185

Weinberg KL (1994) Rockfish assemblages of the middle shelf and upper slope off Oregon and Washington. Fish Bull 92: 620-632

Williams A, Koslow JA, Last PR (2001) Diversity, density and community structure of the demersal fish fauna of the continental slope off western Australia (20 to $35^{\circ} \mathrm{S}$ ). Mar Ecol Prog Ser 212:247-263

Wilsey BJ, Potvin C (2000) Biodiversity and ecosystem functioning: importance of species evenness in an old field. Ecology 81:887-892 
Appendix 1. List of species considered with detail on the abbreviated codes used. ${ }^{*}$ Species not considered in the multivariate analysis (i.e. present in less than $5 \%$ of tows)

\begin{tabular}{|c|c|c|}
\hline Label & Species & Family \\
\hline ANTOMEG & Gaidropsarus biscayensis Collett, 1890 & Gadidae \\
\hline APHIMIN & Aphia minuta De Buen, 1931 & Gobiidae \\
\hline ARGESPY & Argentina sphyraena Linnaeus, 1758 & Argentinidae \\
\hline ARNOIMP & Arnoglossus imperialis (Rafinesque, 1810) & Bothidae \\
\hline ARNOLAT & Arnoglossus laterna (Walbaum, 1792) & Bothidae \\
\hline ARNORUP & Arnoglossus rueppeli (Cocco, 1844) & Bothidae \\
\hline ARNOTHO & Arnoglossus thori Kyle, 1913 & Bothidae \\
\hline ASPICUC & Aspitrigla cuculus (Linnaeus, 1758) & Triglidae \\
\hline ASPIOBS & Chelidonichthys obscurus (Bloch \& Schneider, 1801) & Triglidae \\
\hline BLENOCE & Blennius ocellaris Linnaeus, 1758 & Blennidae \\
\hline BOOPBOO & Boops boops (Linnaeus, 1758) & Sparidae \\
\hline BUGLLUT & Buglossidium luteum (Risso, 1810) & Soleidae \\
\hline CALMMAC & Synchiropus phaeton (Günther, 1861) & Callionymidae \\
\hline CAPOAPE & Capros aper (Linnaeus, 1758) & Caproidae \\
\hline CEPOMAC & Cepola macrophthalma Linnaeus, 1758 & Cepolidae \\
\hline CITHMAC & Citharus linguatula (Linnaeus, 1758) & Citharidae \\
\hline CONGCON & Conger conger (Linnaeus, 1758) & Congridae \\
\hline DIPLANN & Diplodus annularis (Linnaeus, 1758) & Sparidae \\
\hline DIPLVUL & Diplodus vulgaris (Geoffroy St Hilaire, 1817) & Sparidae \\
\hline ECHEMIR* ${ }^{*}$ & Echelus myrus (Linnaeus, 1758) & Ophichthidae \\
\hline EUTRGUR & Chelidonichthys gurnardus (Linnaeus, 1758) & Triglidae \\
\hline GADIARG & Gadiculus argenteus (Guichenot, 1850) & Gadidae \\
\hline GALUMEL* & Galeus melastomus (Vaillant, 1888) & Scyliorhinidae \\
\hline GLOSLEI* & Glossanodon leioglossus (Valenciennes, 1848) & Argentinidae \\
\hline GOBIFRI & Lesueurigobius (Gobius) friesii Malm 1874 & Gobiidae \\
\hline GOBINIG & Gobius niger Linnaeus, 1758 & Gobiidae \\
\hline GOBIQUA & Deltentosteus (Gobius) quadrimaculatus (Valenciennes, 1837) & Gobiidae \\
\hline HELIDAC & Helicolenus dactylopterus Delaroche, 1809 & Scorpaenidae \\
\hline LEPICAU & Lepidopus caudatus (Euphrasen, 1788) & Trichiuridae \\
\hline LEPMBOS & Lepidorhombus boscii (Risso, 1810) & Scophtamidae \\
\hline LEPTCAV & Lepidotrigla cavillone (Lacepède, 1801) & Triglidae \\
\hline LEPTDIE & Lepidotrigla dieuzeidei (Lacépède, 1801) & Triglidae \\
\hline LOPHBUD & Lophius budegassa Spinola, 1807 & Lophiidae \\
\hline LOPHPIS & Lophius piscatorius (Linnaeus, 1758) & Lophiidae \\
\hline MACOSCO & Macroramphosus scolopax (Linnaeus, 1758) & Macroramphosidae \\
\hline MAURMUE* & Maurolicus muelleri (Gmelin, 1789) & Sternoptychidae \\
\hline MERLMER & Merluccius merluccius smiridus (Linnaeus, 1758) & Merluciidae \\
\hline MICUVAR & Microchirus variegatus (Donovan, 1808) & Soleidae \\
\hline MULLBAR & Mullus barbatus barbatus Linnaeus, 1758 & Mullidae \\
\hline MULLSUR & Mullus surmuletus Linnaeus, 1758 & Mullidae \\
\hline OPHCRUF* ${ }^{*}$ & Ophichthus rufus (Rafinesque, 1810) & Ophichthidae \\
\hline PAGEACA & Pagellus acarne (Risso, 1826) & Sparidae \\
\hline PAGEBOG & Pagellus bogaraveo (Brumich, 1768) & Sparidae \\
\hline PAGEERY & Pagellus erythrinus (Linnaeus, 1758) & Sparidae \\
\hline PERICAT* ${ }^{*}$ & Peristedion cataphractum (Linnaeus, 1758) & Peristediidae \\
\hline PHYLBLE & Phycis blennoides (Brünnich, 1768) & Gadidae \\
\hline RAJAAST & Raja asterias Delaroche 1809 & Rajidae \\
\hline RAJACLA & Raja clavata Linnaeus, 1758 & Rajidae \\
\hline SCOHRHO* & Scophthalmus rhombus (Linnaeus, 1758) & Scophthalmidae \\
\hline SCORNOT & Scorpaena notata Rafinesque, 1810 & Scorpaenidae \\
\hline SCORPOR & Scorpaena porcus Linnaeus, 1758 & Scorpaenidae \\
\hline $\mathrm{SCORSCO}^{*}$ & Scorpaena scrofa Linnaeus, 1758 & Scorpaenidae \\
\hline SCYOCAN & Scyliorhinus canicula (Linnaeus, 1758) & Scyliorhinidae \\
\hline SERACAB & Serranus cabrilla (Linnaeus, 1758) & Serranidae \\
\hline SERAHEP & Serranus hepatus (Linnaeus, 1758) & Serranidae \\
\hline SOLEVUL & Solea solea (Linnaeus, 1758) & Soleidae \\
\hline SPARPAG & Pagrus (Sparus) pagrus (Linnaeus, 1758) & Sparidae \\
\hline SPICFLE & Spicara flexuosa Rafinesque, 1810 & Centracanthidae \\
\hline SPICMAE & Spicara maena (Linnaeus, 1758) & Centracanthidae \\
\hline SPICSMA & Spicara smaris (Linnaeus, 1758) & Centracanthidae \\
\hline SQUAACA* & Squalus acanthias Linnaeus, 1758 & Squalidae \\
\hline SYMPNIG* ${ }^{*}$ & Symphurus nigrescens Rafinesque, 1810 & Cynoglossidae \\
\hline TORPMAR & Torpedo marmorata Risso, 1810 & Topenididae \\
\hline TRAHDRA & Trachinus draco Linnaeus, 1758 & Trachinidae \\
\hline TRIGLUC & Chelidonichthys lucernus (Linnaeus, 1758) & Triglidae \\
\hline TRIGLYR & Trigla lyra Linnaeus, 1758 & Triglidae \\
\hline TRIPLAS & Chelidonichthys lastoviza (Bonaterre, 1788) & Triglidae \\
\hline TRISCAP & Trisopterus minutus (Linnaeus, 1758) & Gadidae \\
\hline URANSCA & Uranoscopus scaber Linnaeus, 1758 & Uranoscopidae \\
\hline ZEUSFAB & Zeus faber Linnaeus, 1758 & Zeidae \\
\hline
\end{tabular}

